Vol. 5, No. 2, 2020

\title{
THE SUMMARY OF THE II INTERNATIONAL SCIENTIFIC SYMPOSIUM “SUSTAINABLE DEVELOPMENT - STATE AND PROSPECTS" (SDEV'2020)
}

\author{
Oleksandr Moroz ${ }^{1}$, Olha Kuz ${ }^{2}$, Nadiya Yavorska ${ }^{3}$ \\ ${ }^{I}$ Department of Tourism, \\ ${ }^{2}$ Department of Ecological Safety and Nature Protection Activity, \\ ${ }^{3}$ Department of Ecological Politics and Environment Protection Management, \\ Lviv Polytechnic National University, \\ 12, S. Bandery Str., Lviv, 79013, Ukraine \\ olha.n.kuz@lpnu.ua
}

https://doi.org/10.23939/ep2020.02.063

Received: 12.04.2020

(C) Moroz O., Kuz O., Yavorska N., 2020

The II International Scientific Symposium "Sustainable Development - State and Prospects" (SDEV'2020), organized by the Viacheslav Chornovil Institute of Sustainable Development, was held in the training camp "Polytechnic-2" in Slavske, Lviv Region on February 12-15, 2020. The symposium was coorganized by the Ukrainian Environmental League.

The grand opening of the symposium was held on February 13. By welcoming the participants, the chairman of the organizing committee, Director at the Viacheslav Chornovil Institute of Sustainable Development Prof. Oleksandr Moroz noted that scientific activities on sustainable development are relevant, because the idea of the need to harmonize the relationship between humans and nature has a long history. By sustainable development we mean the development of a society that meets the needs of present generations and does not compromise the ability of the future generations to meet their needs. It is necessary to promote the principles of the sustainable development and promote the formation of a new type of thinking in Ukraine, in which all socioeconomic and socio-ecological processes and phenomena will be viewed through the lens of environmental protection. The symposium was attended by the representatives of higher education institutions from different regions of Ukraine (Lviv, Kyiv, Ivano-Frankivsk, Rivne, Poltava, Kremenchug, Kharkiv, Dnipro) and by foreign guests from Poland, Germany and Austria.

The talks of the participants of the international scientific symposium were discussed at plenary and sectional meetings. There were sections in five areas: Ecology and Balanced Environmental Management;
Environmental Safety and Environmental Protection; Entrepreneurship and Environmental Expertise of Goods; Tourism and Hotel and Restaurant Business; Civil Security (occupational safety, technogenic safety). The talks were given in Ukrainian, Polish and English.

The planetary talks were given by Prof. Oleh Nahurskyy on "Ecological problems of organic agriculture in the concept of sustainable development" [1], by Prof. Myroslav Malovanyy on "Application of encapsulated mineral fertilizers - a way to increase the level of ecological safety of agrotechnologies" [2], by Prof. Volodymyr Bogolyubov on "Principles of balanced nature as a principle for the transition to sustainable rural development" [3], by Prof. Volodymyr Mokryy on "Sustainable development of nature protected UkrainianPolish cross-border territories [4]. Also the planetary talks were given by Dr. Schultheis, Germany on "The competence center cultural landscape - networking and knowledge-transfer for a future-oriented landscape development" [5] and Dr. Buller, Poland on "Ecological security in cross-border cooperation on the example of projects implemented under the Poland-Belarus-Ukraine cross-border cooperation program" [6].

In total there were given 164 talks on the theoretical and applied aspects of sustainable development, the current state of the environment, the use of environmentally friendly environmental technologies, the development of eco-tourism, the study of environmental and economic factors for the development of entrepreneurial activity, environmental expertise of goods and ways of ensuring civil security. The reports of the plenary and sectional meetings were published in the collection of 
materials of the Second International Scientific Symposium "Sustainable Development - State and Prospects". At the final plenary session of the symposium, the Austrian municipal waste management expert Christian Cherner gave a talk on "Municipal waste management -35 years of experience in Austria and Czech Republic (19802015)" and a resolution was adopted containing a number of important proposals. In particular, the need to create a sense of responsibility for the younger generation to preserve and improve the environmental status of the environment, as well as to establish cooperation with foreign higher education institutions and scientific institutions in the field of environmental protection and conservation technologies in order to

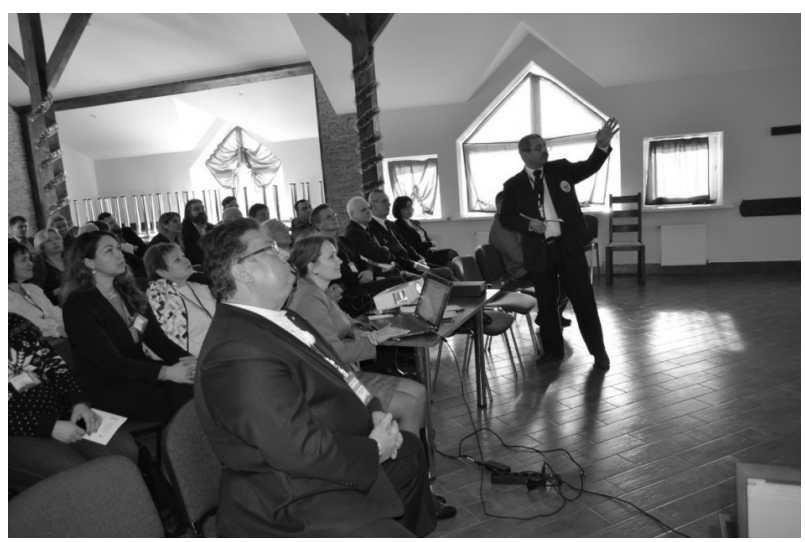

\section{References}

[1] Nahurskyy O., Barabash O., Krylova G., Nahurskyy N., Kachan S., Vasijchuk V., Vichystyj S.: Sustainable Development - state and prospects: Proceedings of the 2-nd International Scientific Symposium SDEV'2020, Ukrainian, Lviv, 2020, 458.

[2] Synelnikov S., Malovanyy M., Nahurskyy O., Tymchuk I.: Sustainable Development - state and prospects: Proceedings of the 2nd International Scientific Symposium SDEV'2020, Ukrainian, Lviv, 2020, 138.

[3] Bogolubov V., Kvasha S., Pustova S.: Sustainable Development - state and prospects: Proceedings of the 2-nd International Scientific Symposium SDEV'2020, Ukrainian, Lviv, 2020, 6. implement joint international projects in educational and scientific activity. The resolution of the II International Scientific Symposium on "Sustainable Development State and Prospects" will be brought to the attention of the executive authorities and local self-government bodies, higher education institutions, scientific organizations and civil society institutes in order to continue discussing the raised issues of sustainable development and jointly address them.

The symposium is scheduled to be held periodically, once every two years. The III International Scientific Symposium "Sustainable Development - State and Prospects" is scheduled for February 2022.

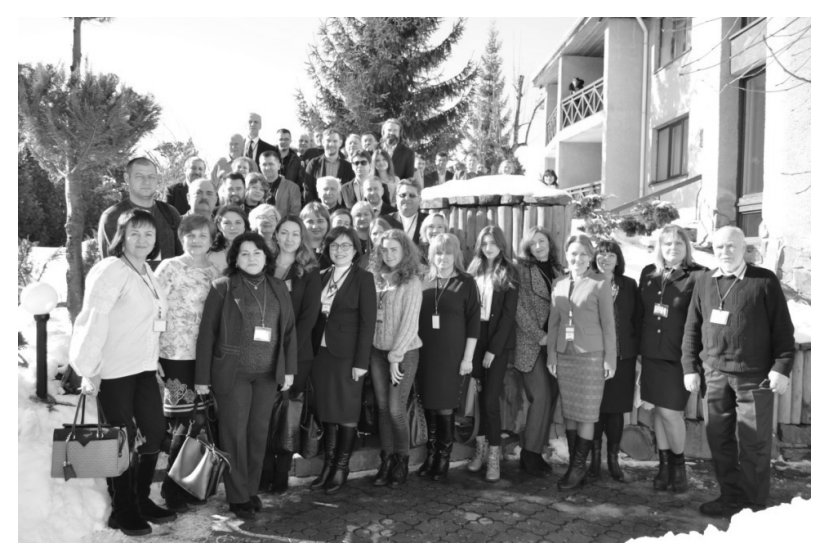

[4] Mokryy V., Kazymyra I., Petrushka I., Jarosiewicz A., Tomin V., Kaminska A., Szmielinska-Pietraszek P.: Sustainable Development - state and prospects: Proceedings of the 2nd International Scientific Symposium SDEV'2020, Ukrainian, Lviv, 2020, 116.

[5] Schultheiß J., Reiss M., Adler K., Jedicke E.: Sustainable Development - state and prospects: Proceedings of the 2-nd International Scientific Symposium SDEV'2020, Ukrainian, Lviv, 2020, 131.

[6] Buller L.: Sustainable Development - state and prospects: Proceedings of the 2nd International Scientific Symposium SDEV'2020, Ukrainian, Lviv, 2020, 95 . 